\title{
Lar seg bare stoppe av ridende politi til hæst - Medicinsk Paradeorchæster fyller 50 år
}

\author{
Medicinsk Paradeorchæster ved Universitetet i Oslo fyller 50 år i april i år, og er i sitt slag det eldste akade- \\ miske fakultetsorkester i landet. Det har inspirert andre studenter til å stifte tilsvarende orkestre på høyere \\ læresteder over hele landet. Iført korrekt formiddagsantrekk og studentluer har Orchæsteret satt preg på \\ Norges hovedstad og har vært en viktig møtested for studenter og leger.
}

I 2011 fyller Universitetet i Oslo, det tidligere Kongelige Frederiks Universitet, 200 år. I en firedel av denne tidsbolken har en av universitetets mest ærverdige og lydfulle institusjoner gledet hovedstadens innbyggere. Det er Medicinsk Paradeorchæster, et velklingende janitsjarorkester som opptrer i korrekt formiddagsantrekk og studentlue. Ikke nok med det, men ifølge Orchæsterets lover spiller de når de vil, hvor de vil og for hvem de vil, og i formålsparagrafen står det presisert at «Orchæsteret lar seg bare stoppe av ridende politi til Hoest.»

Hvordan kunne en så livskraftig institusjon oppstå og ta til seg et så stort livs- og lydrom? Dette skal vi forsøke å svare på, selv om flere av Orchæsterets grunnleggende kulturytringer fortsatt er innhyllet av en viss mystikk.

\section{En lang forhistorie}

Etter at universitetet ble grunnlagt i Oslo, daværende Christiania, var legeutdanning noe av det første de begynte med. Medisinske studenter har alltid hatt interesse for musikk, og gjennom årene har det eksistert en rekke mindre og mer uformelle orkestre ved fakultetet i tillegg til revyer og kabareter. Dette har alltid vært en viktig del av miljøet for de vordende leger. At medisinstudenter laget orkestre, var derfor ikke noe nytt. Et kammerorkester av medisinere var for eksempel aktivt i Oslo i slutten av 1950årene, og til enhver tid var en rekke medisinstudenter med i Universitetets symfoniorkester. I 1950- og 60-årene var omtrent halvparten av alle norske skolebarn med i skolekorps, enten i kortere eller lengre tid. Dette skapte et stort rekrutteringsgrunnlag for amatørmusikken i Norge. At studenter grunnla janitsjarorkester eller messingorkester, var derfor naturlig. Forskjellige blåseorkestre har også vært i drift ved festlighetene rundt studentrevyer.

I Sverige fantes det alt på de tider et par medisinerorkestre. Det mest prominente var ved universitetet i Göteborg og gikk under navnet Hofsmessingsmusik-korpset Blåsljuden. Orkesteret hadde sin egen saluttkanon. Når de var ute og spilte, gikk det alltid en foran og dro på kanonen. Når de skulle begynne å spille, ble kanonen først ladet, og idet skuddet gikk, startet musikken.

I slutten av april 1961 skulle Medisinerforeningen på ekskursjon til den store produsenten av fruktvin, Golden Powerfabrikken på Filtvet. Ellers hadde man ølekskursjon hvert semester og besøkte byens forskjellige bryggerier, men dette var noe sensasjonelt nytt. Primus motor, Ole Didrik Lærum mobiliserte da medlemmene $i$ et jazz- og danseband de kalte Medisinerbanden, tidligere deltakere i medisinerkabaret og studenter med bakgrunn fra skolekorps for å stifte et skikkelig marsjorkester. Baktanken var å bruke det til prosesjonen på vårballet og til 17. mai-spilling. Flere populære numre ble øvd inn, deriblant marsjene «Colonel Boogie» og «Gammel Jægermarsj» i tillegg til «Sønner av Norge» og noen andre låter. Blant ekskursjonens deltakere var det 13 musikanter som dro av sted i bussen iført korrekt formiddagsantrekk, det vil si sjakett eller livkjole og skalk: Kåre Almåsbakk, Oddbjørn Brubakk, Dag Bruusgaard, Olav Albert Christophersen, Per Ivar Gaarder, Ola Heldaas, Eirik Holten, Per Høie, Tor Indrebø, Mikkel Mandt, Anders Mølster, Rasmus Ringdal, Knut Wester, og senere kom også Njål Oftedal og Sigurd Døssland med. Ole Didrik Lærum var formann og musikalsk leder. Høydepunktet var da det nystiftede orkestret gikk spillende inn i den store lagerhallen med tønner stablet fra gulv til tak på hver side. Det var så vidt plass til musikantene. Firmaet hadde akkurat solgt ut lageret, slik at tønnene var tomme. Det ga en mektig resonans, og aldri har det fantes slike «sønner av Norge». Etterpå ble den opparbeidede tørst slukket med smaksprøver på norsk musserende fruktvin.

En god uke senere gikk det nystiftede orkesteret i spissen for opptoget til vårballet fra vorspiel i Det norske medicinske Selskab og langs Drammensveien til KNAhotellet, hvor ballet holdt til (fig 1). Bak musikken kom den gamle tyfusvogna fra Ullevål med hest foran, og med kusk og stormester i setet, og etter den vandret alle de festkledde gjestene. Orchæsteret fortsatte i god stil 17. mai med å delta og spille på den tradisjonelle medisinerfrokosten $\mathrm{i}$ kantina på Rikshospitalet. Deretter gikk det spillende gjennom parken, ned Fredriksgate og endte på Universitetsplassen. I den lille stubben av Karl Johans gate gikk det mot retningen til hovedprosesjonen som var på vei, til politiets store bestyrtelse. De prøvde å vifte musikantene vekk, men uten hell. Under senere spilling på fine vårdager på Karl Johan stoppet Orchæsteret på grønt når det kom til et lyskryss, for siden å marsjere når det skiftet til rødt. Det ble tuting fra bilene, og det passet godt til musikken. Og folk sto på fortauet og moret seg.

Det var ikke tvil om at orkesteret var kommet for å bli. Det fylte et stort behov, ikke bare i medisinermiljøet, men også i studentmiljøet generelt. Når studentene arrangerte noe, skulle det være klingende musikk til. Njål Oftedal og daværende «Formand» trålet byen for å få tak i gamle instrument - og lyktes. Både musikkreparatører og musikkhandlere ga gjerne fra seg gamle, bulkete instrumenter til spottpris når det gjaldt en så god sak.

\section{Orchæsteret deles}

Etter den første spillesesongen var Paradeorchæsteret midt i en rivende utvikling og hadde gjort stor suksess. Likevel truet mørke skyer i horisonten: Nærmere halve kullet skulle til Bergen og ta den kliniske delen av studiet der, inklusive flere av orkesterets stiftere. Dette ble løst salomonisk. Medlemmene delte det orkesteret eide og hadde: sjaketter, skalker, instrumenter og noter samt en ørliten pengesum. Bergen hadde nemlig like stort behov for akademisk hornmusikk som Oslo, og her lå det rikelige muligheter for ny kulturell oppblomstring. Bergenserne dro, og våren 1963 stiftet de Medicinsk blcese et spadserensemble (udi Bergen by), med samme antrekk og repertoar. De andre ble igjen i Oslo og fortsatte med Medicinsk Paradeorchoester.

Ensemblet, eller Blcesen som de kalte seg, ble etter hvert en stor suksess som siden har vært et kjent innslag i bylivet i Bergen. I perioder har de vært større og hatt enda mer vind i seilene enn Paradeorchæsteret, det til tross for at de av stifterne som ble igjen i Oslo konsekvent kalte det nye orkesteret for Metastasen. Det likte de ikke. 
Medicinsk Paradeorchæster ble raskt et populært innslag både i medisinermiljøet og i studentmiljøene ellers. Medlemstallet holdt seg på 20-25 i løpet av 1960-årene, og det var alltid god rekruttering. Paradeorchæsteret ga også utløp for trang til humor og ablegøyer, noe en del av de mest alvorlige og hardtlesende studentene så nokså surt på. Når de spilte i Universitetsparken, fikk de klage fra flittige medisinerstudenter inne på det som den gangen var anatomilesesalen, at de tapte opptil flere leseminutter for hver marsj Orchæsteret spilte. Det var i seg selv en stimulans til økt musikalsk aktivitet. Og det ble brukbare leger til slutt av orkestermedlemmene også.

Uniformen forandret seg også. Det ble slutt på skalkene, og i stedet brukte de studenterluer. Det var i grunnen vel så greit og et godt signal om at medlemmene var studenter. Da marxistbølgen kom etter 1968opprøret var svart studenterlue noe som fikk de såkalte radikalerne til å se rødt, og dette var et viktig tilleggsargument for å bruke dem. Kunne man provosere, så var det en god og moralsk gjerning.

I de neste årene skjedde det en stor knoppskyting. Paradeorchæsteret var alt en sentral del av Oslos kulturliv, og når de marsjerte spillende langs Karl Johans gate på vakre vårdager, var jusstudentene grønne av misunnelse. Anført av Pål W. Lorentzen, i dag fremtredende advokat i Bergen, stiftet de Corpsus Juris og iførte seg dommerkapper og hvite parykker. Her ble det konkurranse, og det skjerpet den musikalske innsatsen. De to orkestrene hadde også vennskapelige fellesarrangementer. I Bergen ble Handelshøyskolen inspirert til å stifte Direksjonsmusikken, og siden gikk det slag i slag med akademiske blæseorkestre ved en rekke av våre høyere læresteder, blant annet Musikselskabet Larmonien ved Universitetet i Bergen.

I løpet av 1960-årene ble en ny, nasjonal tradisjon innført, og Medicinsk Paradeorchæster under ledelse av Jan Erik Bronder, sto bak: SMASH-festivalene for norske akademiske blæseorkestre. Disse samlet orkestre fra hele landet til årvisse stevner både i Oslo, Bergen og Trondheim.

\section{En kultur utvikles}

Medicinsk Paradeorchæster har gjennom årene utviklet sin egen kultur, og dette oppsto gradvis gjennom de første årene. Mange kreative studenter bidro til dette. For det første er det Norges eneste orkester som staves orchoester. Det alene tilsier noe spesielt. Det andre er at den kansellipregede stave- og talemåten er blitt en egen språkkultur som holdes i god hevd. For eksempel er orkesterets leder Formand (eller Phormand), og korpsets fane heter Phanphane. Den ble laget av Sidsel og Knut Wester og bærer mottoet «Det blæs i Noreg». Det finnes også en egen Phanphanesang, skrevet av de samme. Allerede fra de første

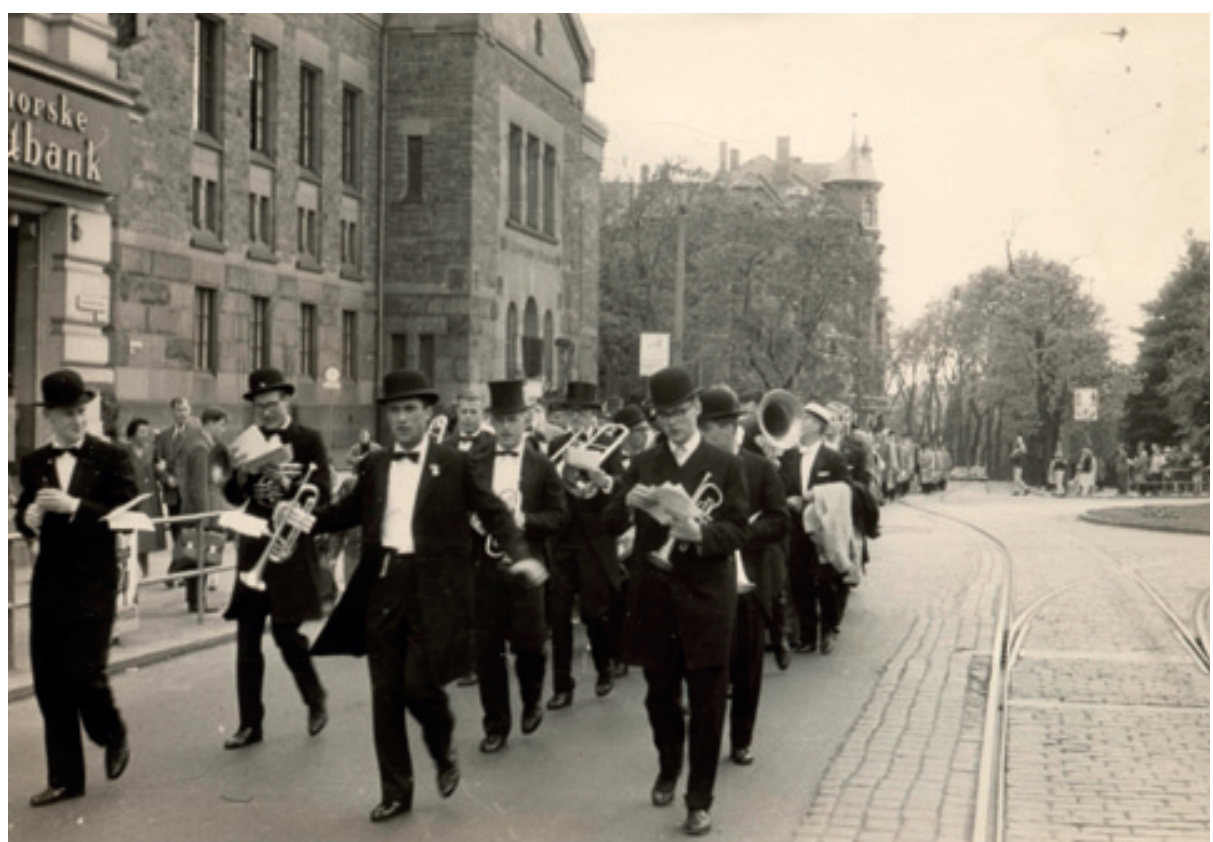

Figur 1 Oppmarsj til Vårballet på Solli plass, mai 1961. Frav: Rasmus Ringdal, Njål Oftedal, Ole Didrik Lærum, Sigurd Døssland, Dag Bruusgaard, Ola Heldaas, Per Høie, Eivind Brudvik, Anders Mølster (skimtes)

årene var det til enhver tid en egen Phanphanebcerer. Orkesteret har sine egne lover, som er basert på en rekke hendelser i de første årene, blant annet flere kontante møter med Oslos politikorps.

Til enhver tid har det vært en hårfin balanse mellom to typer musikanter: Det er de som kan spille, og så er det naturtalentene. Når de første dominerer, blir det musikalsk skikkelig bra, klinger fint og med presisjon. Imidlertid kan det bli litt kjedelig. Her kommer naturtalentene inn, skaper liv og røre og de mest overraskende innfall som ville fått både Mozart og Beethoven til å steile. Men får de for stor innflytelse, kan det bli tvil om hvilket musikkstykke orkesteret egentlig spiller. Ikke minst blir det nokså kjedelig når man bare hører tuting og andre ulyder. En passe balanse mellom disse to ytterpunktene har vært karakteristisk for Paradeorchæsterets mest suksessfulle perioder. Et annet problem var at orkestermedlemmene hadde lett for å bli udisiplinerte. Med masse villspilling mellom musikkstykkene kunne det være vanskelig å skille mellom når orkesteret egentlig spilte og når det var pause. For å motvirke dette innførte ledelsen allerede fra første året, og med hard hånd, et nytt og epokegjørende prinsipp i den akademiske hornblåseverden: Når de ikke spilte, skulle munnstykket puttes i lomma. Det var et effektivt, men kontroversielt tiltak.

Medicinsk Paradeorchæster var en av de første institusjoner i Norge som innførte kjønnskvotering. I lovene het det at Orchæsteret skulle ha en egen damekomité, og formannen i komiteen skulle til enhver tid være «en Mand». Derimot ble etter hvert både formann og dirigent kvinner.

Et tiltak som Paradeorchæsteret innførte i Oslos kulturliv fikk storartet mottakelse. Det begynte en fin vårdag $i$ et av orkesterets første år at det var ute og spilte og marsjerte langs Karl Johans gate. På forhånd hadde medlemmene hatt seg både én og to pils på uterestauranten Nille. Virkningen uteble ikke, og trengselen ble større og større etter hvert som de nærmet seg Stortinget. Rett ved Krogh-statuen brøt de av og marsjerte spillende ned på det underjordiske toalettet. Phanphanebæreren holdt vakt utenfor med Phanphanen høyt hevet, inntil de kom spillende opp igjen. Den gangen var kollektivt besøk på et slikt avtrede svært enkelt, da alle musikantene var menn. Neste dag sto følgende å lese under en større overskrift i Morgenbladet: «En takk» - til de unge musikantene som hadde gledet Oslos publikum med å tre av i det underjordiske, spillende «Sønner av Norge»»». Underskrevet Ernst Sørensen, kultur-redaktør.

Under de musikalske fremføringene introduserte de en rekke nye og naturtalentfulle instrumenter og overraskende musikalske virkemidler. Når de for eksempel spilte sin egen versjon av «La Paloma», var det ett sted hvor melodien gikk opp til en tone med fermate. Da hoppet orkesteret unisont, til og med tubaister og stortrommeslagere. Andre ganger stoppet de etter avtale på én bestemt tone, tok en slurk øl og pratet litt, hvoretter musikken plutselig fortsatte som før.

Foruten SMASH , Bergens- og Trondheimsturneer, ble det fra 1963 fast tradisjon å ta en tur til København. Orchæsteret underholdt på danskebåten og skaffet det danske folk uforglemmelige opplevelser og det danske politiet store forskrekkelser. De var ikke klar over at musikantene bare kunne stanses av ridende politi til Hoest. 
Femårsjubileum og plateinnspilling

Da Medicinsk Paradeorchæster fylte fem år våren 1966, var det en veletablert kulturinstitusjon, en pioner og den førende innen det akademiske hornmusikalske liv. Da fant de ut at tiden var moden for en plateinnspilling. Flere fanfarer og noen andre småstykker som den første Formanden hadde skrevet, var med, og i tillegg skrev han en minisymfoni for blæseorchæster bygd over sagaen om Olav Tryggvason og slaget ved Svolder. Et hovedpoeng var at den gode kongen hadde slett ikke druknet da han hoppet over bord, men hadde klart å svømme til land hvor han levde ennå i beste velgående. I den lyriske mellomsatsen, adagio, symboliserte musikerne dette med resitasjon om kongen til akkompagnement av resten av orkesteret som gurglet etter en god slurk fra den vanlige pilsflasken på innerlomma. Gurglekoret ble en fulltreffer, som stadig ble gjentatt. Musikkstykket bar navnet «Symfoni nr. 2 i e-moll, Den uspilte». Grunnen var at da symfonien ble skrevet, så hadde den ikke vært spilt ennå. Den dagen det skulle gjøres innspilling i et studio, møtte Orchæsteret opp i full uniform med medaljer og studenterlue og blankpussede instrumenter. Teknikeren holdt på å dette av stolen og spurte hva dette skulle bety. Jo, de ville så gjerne at uniformene skulle komme med på opptaket. I alle fall kom de med på bildet som ble tatt i parken på Rikshospitalet med den høyeste beskytter i spissen: professor i rettsmedisin Georg Waaler, som hadde solid musikalsk bakgrunn og dirigerte på opptaket (fig 2).

Til minne om 1968, året som står i opprøret og revolusjonens tegn, komponerte Orchæsterets første Formand en revolusjonsetyde for kor og orkester. Den er karakterisert ved at verket kan bare spilles én gang av det samme orkester. For etterpå finnes det gjerne ikke noe orkester mer. I så måte tok Frédéric Chopin helt feil da han skrev sin revolusjonsetyde for klaver. Hadde den vært ekte, ville det ikke vært noe klaver igjen. Paradeorchæsterets revolusjonsetyde ble også spilt inn på plate, og på plateomslaget er det bilde av tumultene som oppsto. På et visst sted i verket skal blant annet dirigenten slås ned. Handlingen bygger på et fellesslagsmål som en gang fant sted $i$ et ungdomshus på Voss. Ved begge plateinnspillingene ble det laget radioprogram der Orchæsteret stilte i full mundur i Store studio på NRK.

\section{Hva skjedde siden?}

Den ene av oss (ODL) hadde den spennende oppgaven å være Formand, det vil si praktisk og musikalsk leder de første to årene. Siden overtok Arild Kovdal for et par år, deretter ble det Anders Glomstein i noen år. Siden kom Jan Erik Bronder, og deretter Aslak Syse sammen med Georg Høyer og

\section{Det blas i f2oreg:}

\section{ftleitintsk A3araienreljaester}

\author{
Dirigent: professor ìr. mè̀. Grorg đọ̆taaler
}

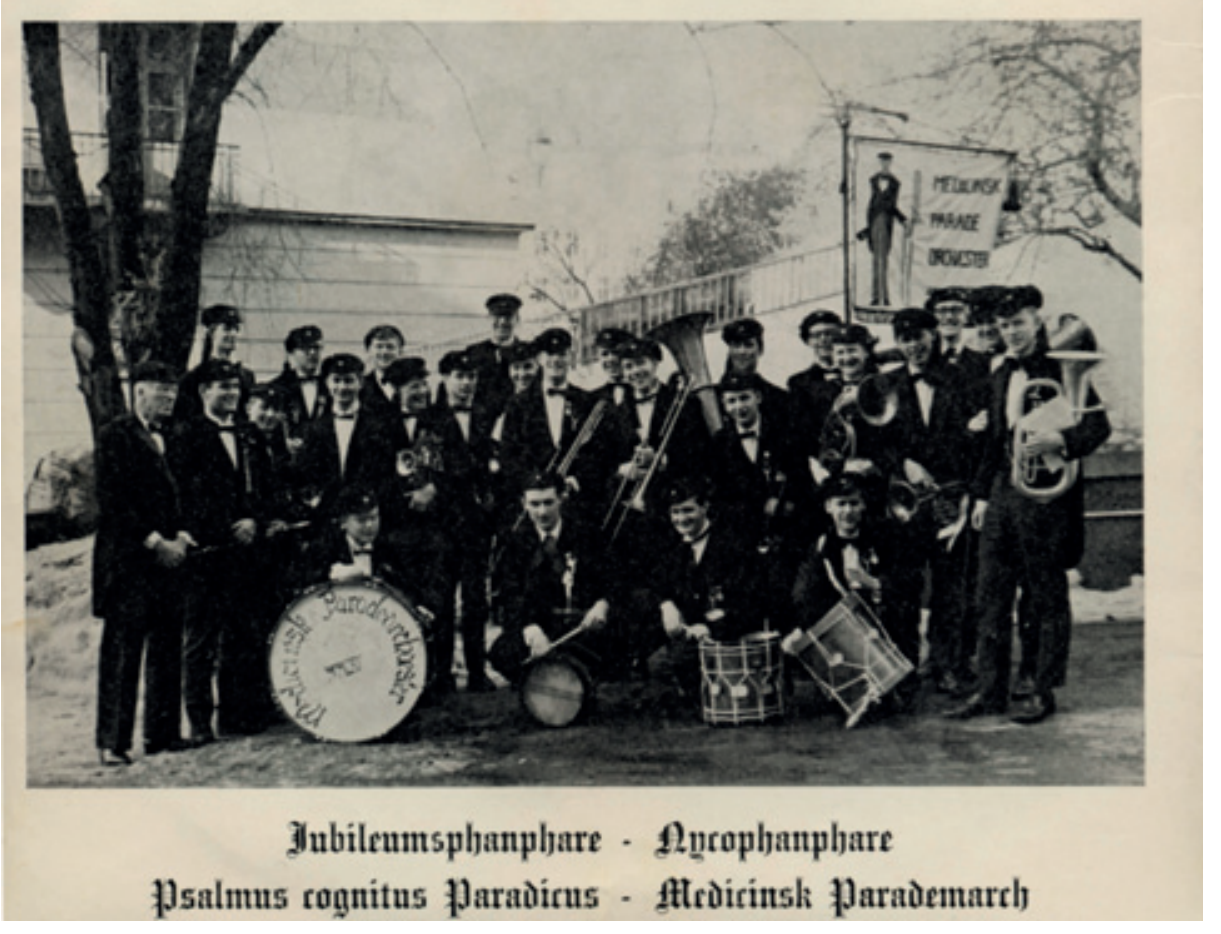

Figur 2 Fra Paradeorchæsterets platecover 1966
Håkon Lie. De første årene fungerte Knut Wester som dirigent og i en kortere periode som vikar for Formanden. Orkesteret hadde en nedgangsperiode i 1970. Den harde studentradikalismen hadde vel gjort sitt for å sette en så borgerlig antrukket institusjon under press. Lærum overtok på ny vervet som Formand i perioden 1970-71. Som motvekt mot de lokale marxistene på Det medisinske fakultet, kom en rekke nye musikere som hadde tatt første avdelings eksamen i utlandet og var kommet inn i klinisk arbeid i Norge. Det ble en verdifull grunnstamme i orkesteret, med en litt annen og videre kulturell bakgrunn enn de hjemlige medisinerne. Orkesteret fikk en ny giv og hadde særlig suksess med å spille bayersk ompamusikk som passet godt til studentsamlinger.

Medicinsk Paradeorchæster har siden hatt mange bordsetninger med musikere, Formænd og dirigenter, og kulturen har stadig utviklet seg videre (fig 3). Det skal den også, for en kultur som blir stillestående, vil snart dø hen. Institusjonen har vært et viktig bindeledd mellom medisinstudenter fra ulike kull, der første års studenter kan bli kjent med og ha fellesskap med eldre studenter. Dette er aktiv nettverksbygging som i tillegg har hatt positive ringvirkninger i yrkeslivet: «Er du også gammel MP'er»?

\section{Paradeorchæsteret i dag}

Det er et livskraftig Orchæster på rundt 30 medlemmer som feirer sitt jubileum i år. Orchæsterets base er etter mange års diaspora fortsatt den sagnomsuste Orchæstergraven i den gamle vaktmesterboligen ved Ullevål sykeus. I takt med omstruktureringen av sykehusene i osloområdet har også Medicinsk Paradeorchæster måttet leve igjennom noen år med vandring. Fra gamle Rikshospitalet i Pilestredet gikk turen til studentpaviljongen på Ullevål sykehus og derfra via blant annet et vaskeri til dagens øvelseslokale. Selv om sykehusledelsen mang en gang har truet med å kaste Orchæsteret ut og sådan stoppe oss, står Orchæstergraven der fortsatt. Den har Carlsberg-grønne vegger og et raffinert møblement innsamlet på dugnad på Oslos beste vestkant, og sikrer at Orchæsterets medlemmer skal kunne slappe godt av mellom de musikalske øktene - tirsdager i partallsuker. Selv et tyveri av alle Orchæsterets instrumenter har ikke klart å stoppe denne viktige kulturinstitusjon.

Nettopp Carlsbergs bryggerier og kongens by København står sentralt i Medicinsk Paradeorchæsters daglige virke anno 2011. Der 17. mai, folkefest og paradering midt imot Hans Majestet Kongens Garde er vårens høydepunkt, er det ingen tvil om at den årlige Hygiæne- et Qualitetskontroll av juleølet til Carlsbergs bryggerier lyser opp i høstmørket som en skinnende cymbal. Etter en natt på danskebåten kommer Medi- 


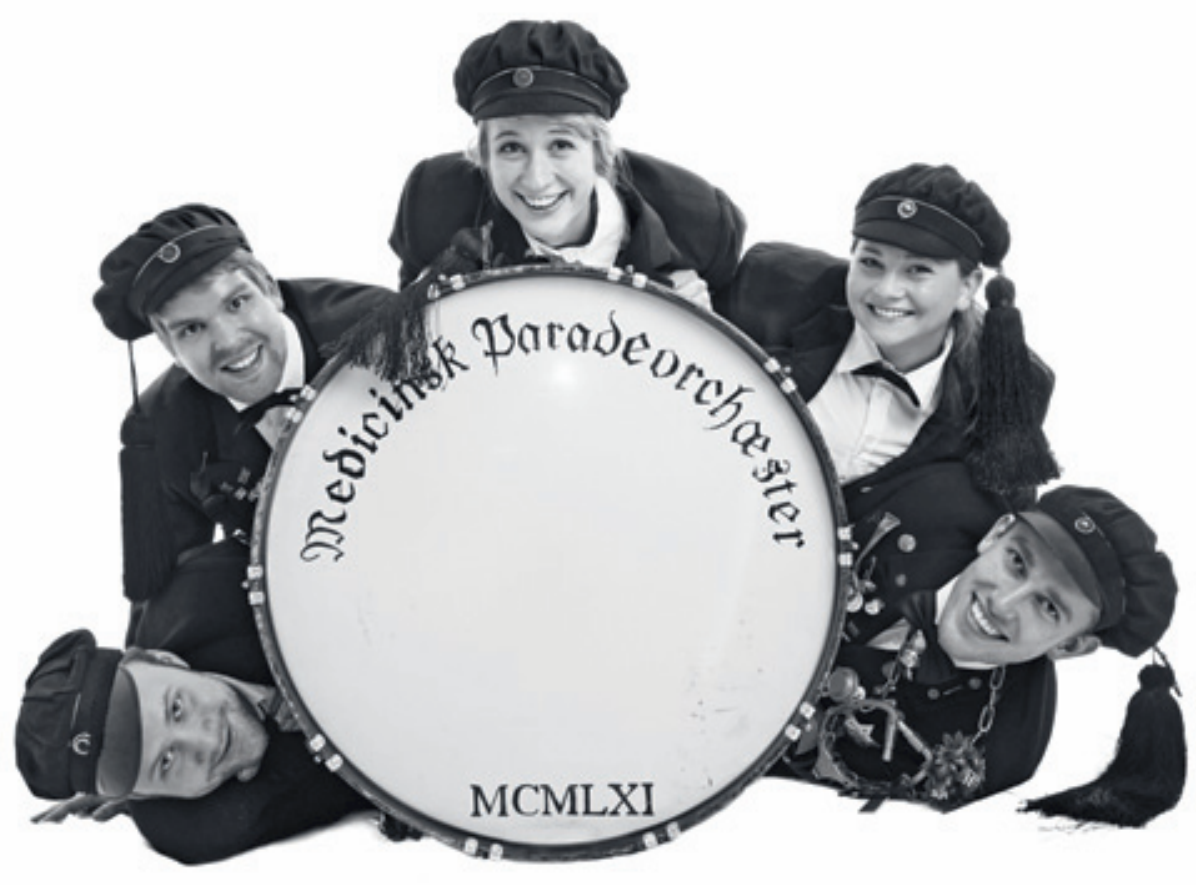

Figur 3 Et knippe fra dagens Medicinsk Paradeorchæster

cinsk Paradeorchæster høyst spillbare til København. Første stopp er den finske ambassades «finske frokost», og Orchæsteret seiler så videre til Sveriges ærverdige ambassade. Unektelig kan en finsk traktering sette sine spor, og ingen glemmer da tidligere Formand Ida Marie Ringerud kalte ambassadørfruen for ambassadåsan, til Orchæsterets store fornøyelse og ambassadepersonellets tilsvarende oppstandelse. Etter en svipptur innom hjemlandets ambassade er siste stopp naturlig nok Carlsbergs bryggerier, hvor «Holmenkollmarsjen» pleier å åpne selv den mest gjenstriringene som medlem er å være vårt ansvar bevisst og huske at vi er på besøk som kontrollører, ikke konsumenter! Få har lyktes godt med denne distinksjonen.

Medicinsk Paradeorchæsters daglige drift består i tillegg til øvelser av en rekke oppdrag. Fortsatt underholder de ved Medicinerforeningens Vårball, og ingen fersk medisinerspire blir døpt før hun eller han har renset øregangen til «Abba Gold».

Orchæsteret leies også inn for å underholde på ulike tilstelninger, og mang en kongress eller selskap har fått en vitamininnsprøyt- ning av uniformerte og paraderende utøvere av akademisk hornmusikk. I 2011 er de både Universitetet i Oslos jubileumsorkester og ski-VM i Holmenkollens offisielle orkester.

I flere år har professor i patologi, Borghild Roald vært Orchæsterets høyeste beskytter, og hun har årlig Orchæsteret på hjemmebesøk for biffbespisning og intimkonsert. Formand i jubileumsåret er Reidar Agdestein, og dirigent er Hege Kristin Netmangen Larsen.

Tross dystre spådommer om korpsmusikkens død og utallige forsøk fra både sykehusdirektører og høyesterettsadvokater på å stanse dem, lever Medicinsk Paradeorchæster i beste velgående. Orchæsteret fyller i dag en viktig rolle, da det forbinder studenter uavhengig av kjønn og kulltilhørighet, og skaper et pusterom i en ellers travel medisinsk hverdag. Å påstå at Medicinsk Paradeorchæster har hjulpet folk til å stå på eksamen, er kanskje å ta hardt $\mathrm{i}$, men det er ikke så langt fra sannheten. Og fortsatt er den felles parolen:

Medicinsk Paradeorchæster spiller: når de vil

hvor de vil

for hvem de vil

så lenge de vil
- med en ny og viktig tilføyelse:

Foruten ridende politi til Hæst kan det imidlertid stoppes av gaaende Gardechef til fots.

\section{Matias Rake}

m.m.rake@studmed.uio.no

Nydalen allé 17

Leilighet 222

0484 Oslo

\section{Ole Didrik Lærum}

Gullfjordungsvegen 1

5700 Voss 